\title{
Comparative Biology of Cycad Pollen, Seed and Tissue - A Plant Conservation Perspective
}

\author{
J. Nadarajan ${ }^{1,2}$ - E. E. Benson ${ }^{3}$ - P. Xaba ${ }^{4}$. \\ K. Harding ${ }^{3}$ - A. Lindstrom ${ }^{5}$ - J. Donaldson ${ }^{4}$. \\ C. E. Seal ${ }^{1}$ - D. Kamoga ${ }^{6}$ - E. M. G. $\operatorname{Agoo}^{7} \cdot$ N. $\mathrm{Li}^{8}$. \\ E. King ${ }^{9}$ H. W. Pritchard ${ }^{1,10}$ \\ ${ }^{1}$ Royal Botanic Gardens, Kew, Wakehurst Place, Ardingly, West Sussex RH17 6TN, UK; e-mail: \\ j.nadarajan39@gmail.com \\ ${ }^{2}$ The New Zealand Institute for Plant \& Food Research Ltd, Private Bag 11600, Palmerston North 4442, New \\ Zealand; e-mail Jayanthi.nadarajan@plantandfood.co.nz \\ ${ }^{3}$ Damar Research Scientists, Damar, Cuparmuir, Fife KY15 5RJ, UK; e-mail: e.benson-damar@tiscali.co.uk; \\ k.harding-damar@tiscali.co.uk \\ ${ }^{4}$ South African National Biodiversity Institute, Kirstenbosch National Botanical Garden, Cape Town, \\ Republic of South Africa; e-mail: P.Xaba@sanbi.org.za; j.donaldson@ sanbi.org.za \\ ${ }^{5}$ Nong Nooch Tropical Botanical Garden, Chonburi 20250, Thailand; e-mail: ajlindstrom71@gmail.com \\ ${ }^{6}$ Joint Ethnobotanical Research Advocacy, P.O.Box 27901, Kampala, Uganda; e-mail: \\ denniskamoga@yahoo.com \\ ${ }^{7}$ De La Salle University, Manila, Philippines; e-mail: esperanza.agoo@dlsu.edu.ph \\ ${ }^{8}$ Fairy Lake Botanic Garden, Shenzhen, Guangdong, People's Republic of China; e-mail: \\ andreali1997@126.com \\ ${ }^{9}$ UNEP-World Conservation Monitoring Centre, Cambridge, UK; e-mail: Emily.King@unep-wcmc.org \\ ${ }^{10}$ Author for Correspondence; e-mail: h.pritchard@kew.org \\ Published online: 5 July 2018 \\ (C) The Author(s) 2018
}

\begin{abstract}
Cycads are the most endangered of plant groups based on IUCN Red List assessments; all are in Appendix I or II of CITES, about $40 \%$ are within biodiversity 'hotspots,' and the call for action to improve their protection is longstanding. We contend that progress in this direction will not be made until there is better understanding of cycad pollen, seed and tissue biology, which at the moment is limited to relatively few $(<10 \%)$ species. We review what is known about germplasm (seed and pollen) storage and germination, together with recent developments in the application of contemporary technologies to tissues, such as isotype labelling, biomolecular markers and tissue culture. Whilst progress is being made, we conclude that an acceleration of comparative studies is needed to facilitate the integration of in situ and ex situ conservation programmes to better safeguard endangered cycads.
\end{abstract}

Keywords Threatened plants · Germination $\cdot$ Storage $\cdot$ In vitro technology Biotechnology 


\section{Introduction}

Cycads are gymnosperms and current cycad families are considered to be remnants of the most ancient group of seed-bearing plants, with origins of the cycad crown dating to c. 200 million years ago (MYA) (Nagalingum et al., 2011) and c. 230 MYA (SalasLeiva et al., 2013). During the Jurassic period (c. 200-145 MYA), cycads are thought to have been relatively common in the world's flora. The evolutionary age estimates and diversification dynamics of cycads depend on the dating method used. Cycad genera either diversified in the Palaeogene (66-23 MYA), and had two diversification rate shifts, or during the Neogene (23-2.6 MYA), with four rate shifts accounting for each of the four richest genera: Cyacas, Zamia, Encephalartos and Macrozamia (Condamine et al., 2015). However, new evidence suggests that today's living species are not much older than $\sim 12$ million years, and are thus not living fossils per se (Litz et al., 2005; Nagalingum et al., 2011; Salas-Leiva et al., 2013). Nonetheless, current cycad species are viewed as evolutionary relicts in the sense that they are surviving representatives of once diverse or abundant groups, having persisted with little morphological change (Nagalingum et al., 2011). They are generally regarded as extremely slow-growing species, with a mean growth rate varying from a maximum of ca. $10-15 \mathrm{~cm}$ per year, in a few taller-growing species, to ca. $1 \mathrm{~cm}$ per year, in many forms with more extreme, xerophytic adaptations and dwarf species (Norstog \& Nichols, 1997).

Cycads (literally Cycadales) comprise three families (Cycadaceae, Stangeriaceae and Zamiaceae) and consist of a total of 10 accepted genera and 348 accepted species, divided as follows: Bowenia (2), Ceratozamia (30), Cycas (114), Dioon (15), Encephalartos (65), Lepidozamia (2), Macrozamia (41), Microcycas (1), Stangeria (1), and Zamia (77) (Calonje et al., 2017; Osborne et al., 2012). The species are distributed in warmer areas of North and South America, Africa, Asia and Australia. Interestingly, cycad species have a near symmetrical latitudinal distribution north and south of the equator, with peaks at latitudes c. $27^{\circ} \mathrm{S}$ and $18^{\circ} \mathrm{N}$ (Fragniere et al., 2015). Species richness is relatively low at the equator, with no species in temperate latitudes $>40^{\circ}$. The Caribbean and northeast Australia represent the two most diverse floristic regions, with c. 70 species each; while 38 Encephalartos species and 31 Cycas species are found in the Usambara-Zululand and Indochinese regions respectively (Fragniere et al., 2015). Cycads occur at relatively low elevations (mean of $565 \mathrm{~m}$ ); only four species reach above $2000 \mathrm{~m}$ (Fragniere et al., 2015).

In many instances, individual species tend to exist as small, isolated populations in transformed habitats. Such biogeographical restrictions have contributed to a high estimate for the risk of cycad extinction based on the IUCN Red List categorisation which relates to the area of occupancy (AOO) and extent of occurrence (EOO). Donaldson (2003) reported $62 \%$ of cycads as being threatened with extinction, making them the most threatened group of plant species on Earth. This estimate has been confirmed recently with an analysis of the 2016 IUCN Red List (Table 1), showing that c. 60\% of cycad species assessed were either Critically Endangered (CR), Endangered (EN) or Vulnerable (VU) (Fragniere et al., 2015; Marler \& Marler, 2015; IUCN, 2016). Primarily, CR species are from the genera Encephalartos, Zamia and Cycas (Table 1). In comparison, it has been estimated that just over one fifth of all plant species might be threatened with extinction, and the habitat with the most threatened species is overwhelmingly tropical rain forest (Brummitt et al., 2015). Risks of extinction in the natural habitat are exacerbated by complex reproductive cycles and dependencies on other species for $\mathrm{N}$-fixation, pollination and seed dispersal. 
Table 1 Cycad species in the three families assigned Critically Endangered (CR), Endangered (EN) or Vulnerable (VU) status

\begin{tabular}{llll}
\hline Family & Genus & $\begin{array}{l}\text { Conservation status of } \\
\text { species: CR / EN / VU (n) }\end{array}$ & Total threatened species (n) \\
\hline Cycadaceae & Cycas & $11 / 16 / 30$ & 57 \\
Stangeriaceae\# & Stangeria & $0 / 0 / 1$ & 1 \\
Zamiaceae $\Phi$ & Encephalartos $*$ & $17 / 10 / 15$ & 42 \\
& Ceratozamia & $7 / 12 / 3$ & 22 \\
& Dioon & $0 / 5 / 6$ & 11 \\
& Macrozamia & $0 / 8 / 9$ & 17 \\
& Microcycas & $1 / 0 / 0$ & 1 \\
& Zamia & $16 / 12 / 12$ & 40 \\
& $\Sigma$ & $191(+4)^{*}$ \\
\hline
\end{tabular}

\footnotetext{
A total of 303 species were assessed. Data collated from Fragniere et al. (2015) and IUCN (2016)

\# no species in the genus Bowenia are listed as CR, EN or VU

$\Phi$ no species in the genus Lepidozamia are listed as CR, EN or VU

*plus four species that are extinct in the wild (Encephalartos brevifoliolatus, E. nubimontanus, E. relictus and E. woodii)
}

Cycads are popular and charismatic species for collectors and landscaping, and this has resulted in an increase in wild-sampling, which has also contributed to rarity. Excessive and illegal harvesting of mature cycads from natural populations has caused colony destruction and the extinction of several wild populations. Threats to wild cycads also include habitat destruction for farming, mining and urban development, habitat modification, traditional use (medicinal), invading alien vegetation and, increasingly, climate change and phyto-pathological threats.

In addition to biogeographical limitations, cycads are vulnerable to anthropogenic activities and require particular conservation attention. An example of the urgency assigned to the conservation of cycads is that $6 \%$ of the 120 species listed by the State Forestry Administration (SFA) of China for urgent integrated (in situ and ex situ) conservation intervention are Cycas species, e.g., C. chanjiangensis, C. debaoensis, $C$. dolichophylla, C. fairylakea, C. hongheensis, C. szechuanensis and C. taiwaniana (Wade et al., 2016).

The question then arises: What type of strategies are required to improve the conservation status of cycads? The concept of taking an integrated conservation approach for cycad species was presented at the 9th International Conference of Cycad Biology (Pritchard et al., 2011). As for other 'plant species with extremely small populations' (PSESP; Ma et al., 2013; Wade et al., 2016), a range of innovative interventions are required to ensure the integrated conservation of highly threatened species (Pritchard et al., 2014; Wade et al., 2016). These include: pollen collection, storage and use to artificially pollinate 'cones' in the field so as to enhance quality seed output and potentially widen the genetic diversity of cycad populations; seed treatments for germination; and tissue use for provenance assessment and propagation. However, such actions depend on a far better understanding of many aspects of the biology of cycad pollen, seed and tissues. 


\section{Pollen and Reproductive Biology}

Each cycad genus has unique reproductive and vegetative characteristics. However, all cycads are dioecious where each individual plant is strictly male or female throughout their life cycle. The pollen (on the male plant), and also the ovules (of the females) are produced on sporophylls which are aggregated as cones. Cycad cones vary in size, with female cones ranging from $<5 \mathrm{~cm}$ long to $1 \mathrm{~m}$ long, and weighing up to $40 \mathrm{~kg}$. In certain species the cones are brightly coloured, possibly to attract animal pollinators and seed dispersers (Norstog and Nicholls, 1997). Pollen cones can take several months from emergence to progress to pollen shed, e.g. four months in Encephalartos altensteinii (Xaba, P., pers. comm).

According to Fernando et al. (2010) there is considerable diversity in male gametophytes amongst the four orders of gymnosperms (Cycadales, Ginkgoales, Coniferales and Gnetales). The differences occur in pollen and pollen tube morphology, development and cell composition (Yatomi, et al., 2002; Fernando, et al., 2005; Williams, 2008), sperm delivery (zooidogamy and siphonogamy) (Norstog, 1977) and the duration of pollen germination and fertilization (Chamberlain, 1935; Donaldson \& Bösenberg, 1995; Norstog \& Nicholls, 1997). Despite these differences, cycad pollen still possesses traits similar to anemophilous germplasm in that: a) it lacks a pollenkitt, a liquid fatty substance on the covering pollen grain that attracts insects in entomophilous angiosperms; b) most have an orbicule, which is a small acellular structure of sporopollenin (Pacini et al., 1999); and c) it has a multi-layered, thick sporoderm (Pacini, et al., 1999), which enables it to withstand desiccation, possibly as a result of this gymnosperm's prolonged pollination period.

The similarities of entomophilous cycad pollen traits with that of anemophilous gymnosperms suggest that cycad pollen is robust, and well adapted to cope with detrimental environmental conditions. Various studies on pollen morphology in a number of South Africa cycad species revealed similarity in respect of shape and surface sculpturing between species unlike in any other group of plants (Marshall et al., 1989). Cycad pollen ranges in size, being c. $11 \mu \mathrm{m}$ in Macrozamia miquelii, $23 \mu \mathrm{m}$ in Ceratozamia kuesteriana (Dehgan and Dehgan, 1988), and $24.9 \mu \mathrm{m}$ in Cycas circinalis (Raju and Rao, 2011). Fully hydrated pollen of Encephalartos latifrons is globular in shape and has grains of about $100 \mu \mathrm{m}$ in diameter (Fig. 1).

Cycad pollen goes through nine developmental stages leading eventually to two spermatozoids (Singh, 1978; Ouyang et al., 2004). These spermatozoids are released from the pollen tube sac into the pollination chamber, following which one swims to fertilise the egg cell nucleus and the other fuses with the egg cell. The process is termed as single fertilization (Gifford and Foster, 1988; Chamberlain, 1935; Stanley and Linskens, 1974). This contrasts with angiosperms, which undergo double fertilization. Microcycas is the only known cycad that develops 16 spermatozoids and this is thought to be an ancestral characteristic (Norstog \& Nicolls, 1997) not a derived trait (Nostog et al. 2004).

The entire process, from the deposition of pollen on the micropyle, followed by pollen tube growth and fertilization of the egg, takes considerably longer in cycads and other gymnosperms than in angiosperms. Pollination may occur three to seven months prior to fertilization. For example, in Encephalartos altensteinii it takes between 99 and 120 days from pollination to fertilization (Donaldson \& Bösenberg, 1995). In contrast, 


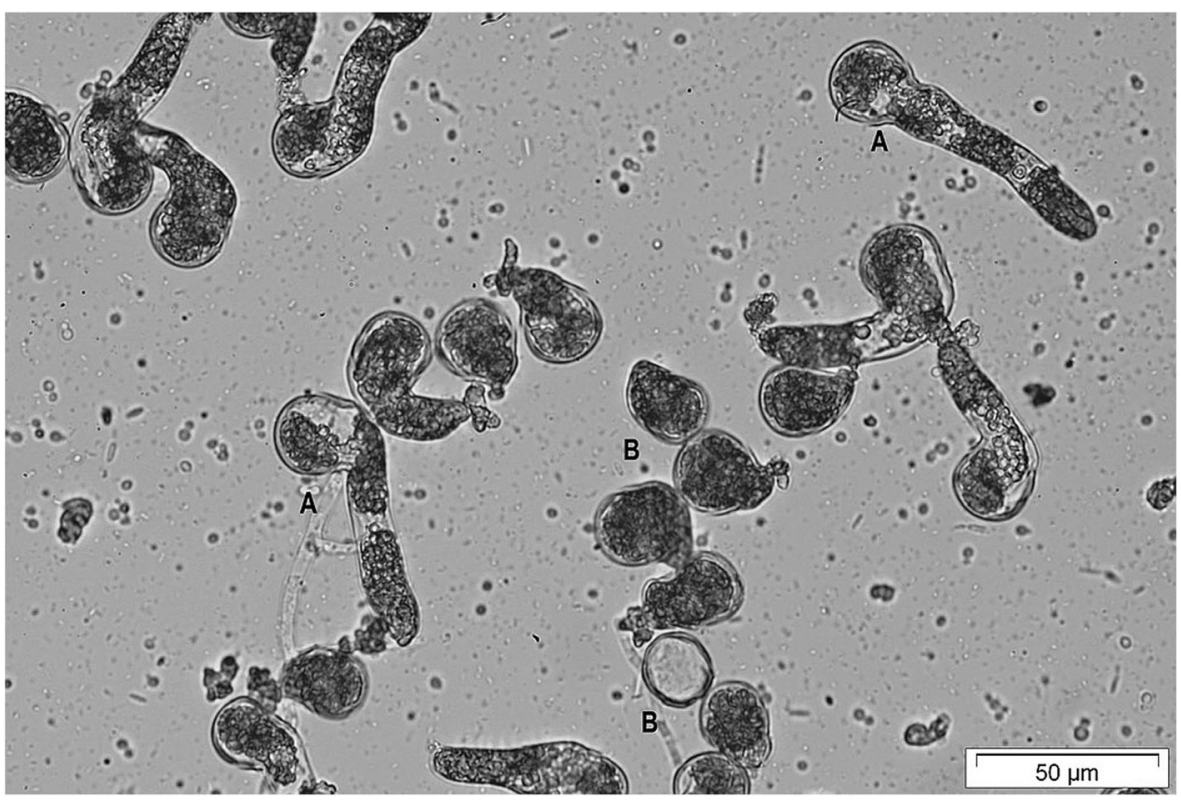

Fig. 1 Encephalartos latifrons pollen germinating in vitro after $48 \mathrm{~h}$ incubation. $\mathrm{A}=$ pollen grains at various stages of tube growth and elongation; $\mathrm{B}=$ non germinated pollen (Xaba, 2014)

fertilization intervals in angiosperms are usually a matter of hours (Norstog \& Nicholls et al., 1997) or minutes (Williams, 2008).

Although all gymnosperm pollination was thought to be anemophilous (i.e., wind pollinated), pollination of cycads by insects (entomophily) has been reported widely (Stevenson et al., 1998) and proven experimentally in seven out of 10 extant genera: Bowenia, Cycas, Encephalartos Lepidozamia, Macrozamia, Stangeria and Zamia (Xaba, 2014).

Reproduction by individual plants can be annual, but may be sporadic or in intervals of up to or $>15$ years, depending on species and environmental conditions (Liddle, 2009). For example in Dioon edule coning frequency is 3-9 years and 10-52 years in male and female plants respectively (Vovides, 1990). In nearly all cycads there is a marked and regular periodicity in cone initiation and development; this cycle can be retained even when the specimens are transported from the wild, often into different latitudes, hemispheres and climates. Many species tend to initiate cones in the spring, are pollinated in the summer and set seeds in late autumn or winter (Norstog and Nicholls, 1997). However, there are marked differences between genera and between species in the same genus with respect to the timing of their reproductive phases. For example, Zamia integrifolia develops cones in the autumn and is pollinated in December, but these stages occur several weeks later in north Florida than they do in the Miami area, $500 \mathrm{~km}$ to the south (Norstog and Nicholls, 1997). One factor for this may be that a more temperate-zone environment (e.g., thermo- or photo-period) may inhibit, or at least not stimulate, 'cone' induction. This area of cycad biology is not well studied and offers the opportunity for field and laboratory-based research.

During pollen shedding in cycads, the sporophylls on the pollen cone loosen to expose pollen sacs, which eventually dry out to liberate pollen grains into the 
atmosphere (Chamberlain, 1935). During this period, the sporophylls in some section of the seed 'cones' typically separate for a number of days to allow insect vectors and the transfer of pollen directly into the vicinity of the micropyle (Donaldson, 1997). A number of cycad species have been observed to have different lengths of cone opening, or receptive, periods. For example, Encepalartos inopinus cones are reported to be receptive for only four days (Grobbelaar, 1996). The second phase of pollen development begins after pollen is carried to the ovule and is drawn into the pollen chamber by resorption of a pollination droplet. This is typical of all gymnosperms (Chamberlain, 1935). Pollination drops have multiple functions: influencing pollen germination and tube growth; defending the ovule from pathogens; providing a food reward to insect pollinators. Proteins of the pollen drop in cycads represent the degradome and generally contain higher proportions of proteins localised to intercellular spaces (Prior, 2014).

One feature of pollen cone biology that has received considerable attention is thermogenesis. Since Poisson's (1878) early study much evidence has emerged to support this (Jacot-Guillarmod, 1958) with the most extensive evidence showing thermogenesis in 42 out of 43 species tested across ten genera (Tang, 1987). Thermogenesis is mostly associated with insect, especially beetle, pollination where volatile odours as the result of cone heating could indicate food, mating opportunities and heat resources (Thien et al., 2000; Terry et al., 2004; Suinyuy et al., 2010; Tang, 1987). Since thermogenesis can influence the timing of insect movement between cones, it is reasonable to assume that receptive female cones, and especially the presence of pollination droplets, would be synchronised with periods of heating and insect dispersal from male cones.

\section{Storage}

Because cycads are dioecious the collection, storage and creation of pollen banks for medium to long-term preservation and germplasm exchange is highly desirable. Indeed, artificial pollination may be necessary in cycad ex situ collections to ensure the setting of viable seed (Tang, 1986). The habitat and location of ex situ collections may mean a lack of suitable pollinators. In addition, such collections typically have limited numbers of each plant species. To counteract such a limitation, and based on microsatellite marker assessment of nearly 600 plants of Zamia decumbens, Griffith et al. (2015) recommended that collections can better conserve the genetic diversity of in situ populations as long as multiple accessions are made over more than one year and the following two approaches are taken: 1) species biology information informs the collecting strategy; 2) each population is managed separately.

Chamberlain (1926) reported that cycad pollen could last about a month in ambient atmospheric conditions but recent studies showed that different cycad genera varied in responses to similar storage environments (Tang, 1986). Furthermore, Mostert (2000) showed that pollen within the Encephalartos species differs in its ability to retain viability at sub-zero storage temperatures. Interestingly, Osborne et al. (1992) reported an anomalous cyclic viability in $C$. thouarsii pollen, where the pollen showed a dormancy-like phenomenon when tested every six months over a three years period. Osborne et al. (1991, 1992) also reported that Encephalartos pollen could be stored for three to five years at $-15^{\circ} \mathrm{C}$.

Artificial pollination using short- to longer-term stored pollen may also be important in in situ conservation projects where plants are too far apart for pollination to occur, as in 
E. latifrons (Daly et al., 2006) and E. middelburgensis (P. Xaba, SANBI, RSA, pers. comm.) or where no pollinators are present. The two main methods for artificial pollination of cycads involve the injection of pollen between the loose sporophylls by puffing (dry method) or squirting in an aqueous solution (wet method) (Grobbelaar, 2002). The most efficient pollination methods may vary between species and dry pollination is recommended for Bowenia, Ceratozamia, Chigua, Cycas, Dioon, Microcycas, Stangeria and Zamia; wet pollination is suggested for Encephalartos, Lepidozamia and Macrozamia (Grobbelaar, 2002). However, E. ferox had more viable seed $(82 \%)$ using a dry method (Tang, 1986). Xaba (2014) observed that seed germination and embryo presence was greater in E. altensteinii than E. latifrons irrespective of the use of dry or wet pollination. Interestingly, wet pollination in E. latifrons resulted in significantly lower seed germination and fewer embryos compared with the dry method, indicating potentially critical relations between pollen viability and environmental conditions. In orchids, humidity levels can impact on both lifespan and immediate viability, e.g., following the imposition of desiccation stress (Marks et al., 2014). Evidence of drying stress has also been seen in E. latifrons pollen after $24 \mathrm{~h}$ and 15 days of treatment with silica gel; in contrast, E. altensteinii pollen retains $>60 \%$ germination after these treatments (Xaba, 2014). Similar pollen research is needed for a range of cycad species.

Whilst cycad pollen banks have been established by a number of botanic gardens, research on pollen germination and storage remains limited for most cycad groups. Osborne et al. (1992) established that stored pollen can be used to give consistent fertilization outcomes, demonstrating that asynchronous coning in cycads can be surmounted as pollen retained $50 \%$ viability for up to two years when stored at $0{ }^{\circ} \mathrm{C}$. Similarly Xaba (2014) noted considerable success in storing silica gel dried pollen of 17 species of Encephalartos at $-15^{\circ} \mathrm{C}$ over a three year period. Over this storage period, there was no obvious difference between the remaining viability of $E$. latifrons from both wild and cultivates sources (Xaba, 2014). For the same lots of pollen, viability loss over 8 years followed a sigmoidal pattern (Xaba, 2014) typical of other pollens (e.g., Marks et al., 2014). Huang (2011) stored pollen of C. revoluta at $-80^{\circ} \mathrm{C}$ for 500 days without obvious loss of viability. Studies on Cycas species by Yang et al. (2009) involved the testing of various media and storage conditions. Storage temperature affected pollen viability, which was retained for 4 months at $0{ }^{\circ} \mathrm{C}$; pollen viability did not show a significant loss after preservation in liquid nitrogen at a water content of $13.2-15.5 \%$. Cryostorage is an accepted approach for many groups of species, such as fruit trees and orchids (Ajeeshkumar and Decruse, 2013), and may be an option for cycads as cryopreserved pollen of C. elongata yielded $90 \%$ seed set (Yang et al., 2009). However, cycad conservation and sustainable use through pollen preservation is hindered by limited research and baseline data on reproductive biology, pollen storage behaviour and in vitro manipulations to assess viability.

\section{Germination}

As for other species, cycad pollen germination and pollen tube growth is influenced by several environmental factors, particularly temperature and moisture (relative humidity), (Stanley and Linskens, 1974). In in vivo environment, such effects are realised through a combination of external ambient conditions and the internal temperature of the cone as affected by thermogenesis when receptive. 
Pollen viability / germination can be assessed in vitro by mixing the pollen with a solution comprising $10 \%(\mathrm{w} / \mathrm{v})$ sucrose and $0.005 \%(\mathrm{w} / \mathrm{v})$ boric acid (Osborne et al., 1992; Mostert, 2000) at a ratio of $20 \mathrm{mg}$ pollen to $200 \mu \mathrm{L}$ medium. Then a $15 \mu \mathrm{L}$ droplet is suspended upside down on a Petri dish lid over water to prevent drying out (Xaba, 2014). After $48 \mathrm{~h}$ at $28^{\circ} \mathrm{C}$ in the dark, the pollen drop is diluted and tube emergence assessed under a microscope (Fig. 1). For fresh pollen of E. altensteinii and E. latifrons in vitro germination can be around $80 \%$ (Xaba, 2014).

Pollen germination (in all plant species) is highly temperature sensitive. In cycads, evidence suggests that the optima are $15-35^{\circ} \mathrm{C}$ for $E$. altensteinii, but only between 25 and $30^{\circ} \mathrm{C}$ for $E$. latifrons (Xaba, 2014). The stricter temperature requirement for pollen germination in the latter species provides a much smaller window of opportunity for efficient pollen tube germination and growth, due to the restricted time that the ovulate cone temperature in the natural environment overlaps with this temperature zone (Xaba, 2014). At least for the two species mentioned above an in vitro pollen quality assessment at $28^{\circ} \mathrm{C}$ appears to be appropriate.

Pollen viability testing using stains has also been carried out with nitroblue tetrazolium stain (Tang, 1986); acetocarmine and Alexander's stain (Mostert, 2000) and aniline blue (Kay et al., 2011). In addition, Osborne et al. (1992) showed best results for cycad pollen germination using the hanging-drop assay with $15 \%$ sucrose solution with $0.005 \%$ boric acid at $28{ }^{\circ} \mathrm{C}$ and incubated for $48 \mathrm{~h}$. Later Moster (2000) found that 5 and $10 \%$ sucrose, with a similar concentration of boric acid, yielded comparable results.

\section{Seed Biology for Conservation and Use}

Whilst much is known about the seed biology of gymnosperms in general, little is known about the seed biology of cycads, either for storage or germination. Moreover, autecology studies tend to focus on plant characteristics, such as coning time, rather than seed traits (mass, storage, germination). Nonetheless, seed yield has been recorded in some species. For example in Dioon edule, mature female cones weigh around 2.5$5 \mathrm{~kg}$ and yield about 80-230 seeds (Vovides, 1990). One estimate indicates that Zamia amblyphyllidia yields only 15 seeds per cone (Negron-Ortiz et al., 1996).

Seed morphological features of cycads have been investigated in a few species. Mature seeds of five Cycas species (C. revoluta, C. media, C. normanbyana, $C$. taiwaniana and $C$. wadei) have a three-layered coat consisting of the sarcotesta, sclerotesta and a thin membraneous jacket (Dehgan and Yuen, 1983). The nutritional value of starch in the sarcotesta provides an incentive for local land dispersal by mammals, for example $E$. whitelockii seed by baboons and monkeys (Kamoga, D., pers. comm). Seeds of Cycas species in the section Rumphiae, such as C. circinalis and C. thouarsii, have an additional spongy layer that causes flotation and could enable long-distance dispersal by river or ocean currents. Seeds of species in this taxonomic section tend to be large and buoyant regardless of viability, whilst seeds in other taxonomic sections in Cycas, such as section Asiorientialis, containing the well-known species Cycas revoluta, have relatively small seeds that only float when inviable.

In cycads, small is a relative concept, as seeds are often 15-50 mm long (Table 2) and seed weights are all relatively large, from 1 to $25 \mathrm{~g}$ : Bowenia spectabilis (1.2 to $2.3 \mathrm{~g})$, Macrozamia spiralis (3.2 g), Cycas thouarsii (6.7 g), Encephalartos 


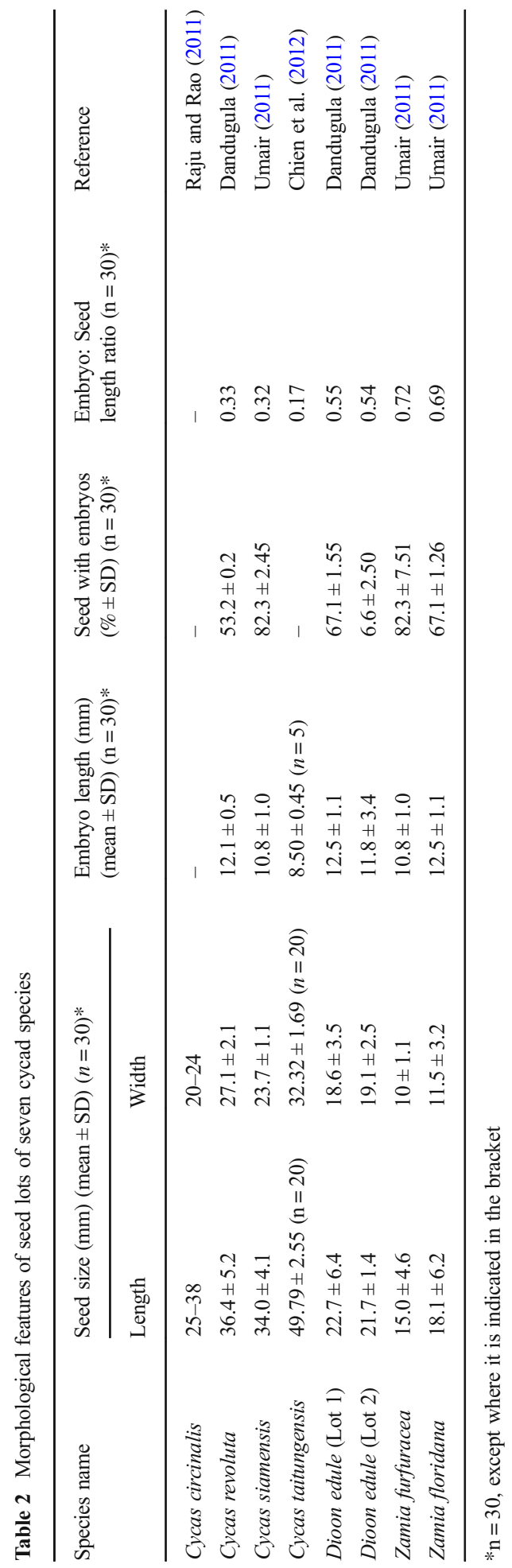


hildebrandtii (7 g), Macrozamia dyeri (16 g), Lepidozamia hopei (18 g), Macrozamia fraseri (19 g) and Cycas rumphii (25 g) (Seed Information Database; http://data.kew. org/sid/). In other angiosperms, particularly tropical trees, the larger the seed mass the greater the likelihood that the seed is desiccation sensitive (Dickie and Pritchard, 2002; Daws et al., 2006).

\section{Storage}

Globally, cycad conservation through seed storage presents complex challenges. Knowledge of seed biology and storage behaviours is limited for most cycad taxa, compared with other plant groups. The Seed Information Database (http://data.kew. org/sid/) only lists seed storage biology data for four Cycas species and one species each in Encephalartos and in Macrozamia. The compiled botanical information on cycad seed storage covers $<2 \%$ of species in the Cycadales.

Cycas angulata, C. armstrongii, C. media and Macrozamia reidlei germinated after sun-drying (Langkamp and Plaisted, 1987) and the possibility exists that the seeds could be orthodox in their storage response, i.e., the seeds can tolerate rapid artificial drying to $15 \% \mathrm{RH}$ and storage at $-20{ }^{\circ} \mathrm{C}$. This remains to be established, however. For C. revoluta the seeds had $92 \%$ germination after 6 months air-dry storage at $2{ }^{\circ} \mathrm{C}$, compared with $42 \%$ germination when stored open at $22{ }^{\circ} \mathrm{C}$ (Dehgan and Schutzman, 1989). This suggests that seeds of this species are not recalcitrant (i.e., not highly desiccation sensitive). E. natalensis seeds also seem to be quite robust in storage, as Forsyth and van Staden (1983) report that seeds can be stored dry or moist. Similarly, Zamia integrifolia is reported to have $77 \%$ germination after 1 year air-dry storage at $5{ }^{\circ} \mathrm{C}$ (Witte, 1977).

Overall then, the main restriction to developing a strategy on the ex situ conservation of cycads in seed banks is a lack of baseline data on storage behaviour, combined with challenges in securing adequate seed supplies, especially in the case of rarer species.

\section{Germination and Dormancy}

The level and timing of seed germination in cycads varies between species. It has been observed that seeds of Microcycas and Cycas revoluta sometimes begin germination even while in the cone, and less than three to four months after fertilisation (Chamberlain, 1935, Norstog and Nicholls, 1997). In contrast, E. latifrons, a critically endangered cycad propagated at Kirstenbosch National Botanical Garden (KNBG), shows low seed germination (Xaba, 2014). Generally, cycad seed is sown to germinate around $25-30{ }^{\circ} \mathrm{C}$ (Table 3). This is true for C. revoluta (Frett, 1987) and Zamia seed (Witte, 1977), although lower temperatures of $15-20{ }^{\circ} \mathrm{C}$ have also been reported for C. revoluta (Zarchini et al., 2011).

Slow germination is known to be a feature of many cycads. Frett (1987) observed that Cycas revoluta seeds take up to a year to germinate: removal of the pulp and sowing in the dark have been observed to increased germination after scarification (up to $2 \mathrm{~h}$ ) with sulphuric acid, but the application of gibberellic acid, a plant hormone and well known dormancy-breaking chemical, does not appear to provide any enhancement. There is some evidence that species with a thick sclerotesta (C. revoluta, $C$. circinalis, Zamia floridana, Z. furfuracea) may be rather impermeable to water 


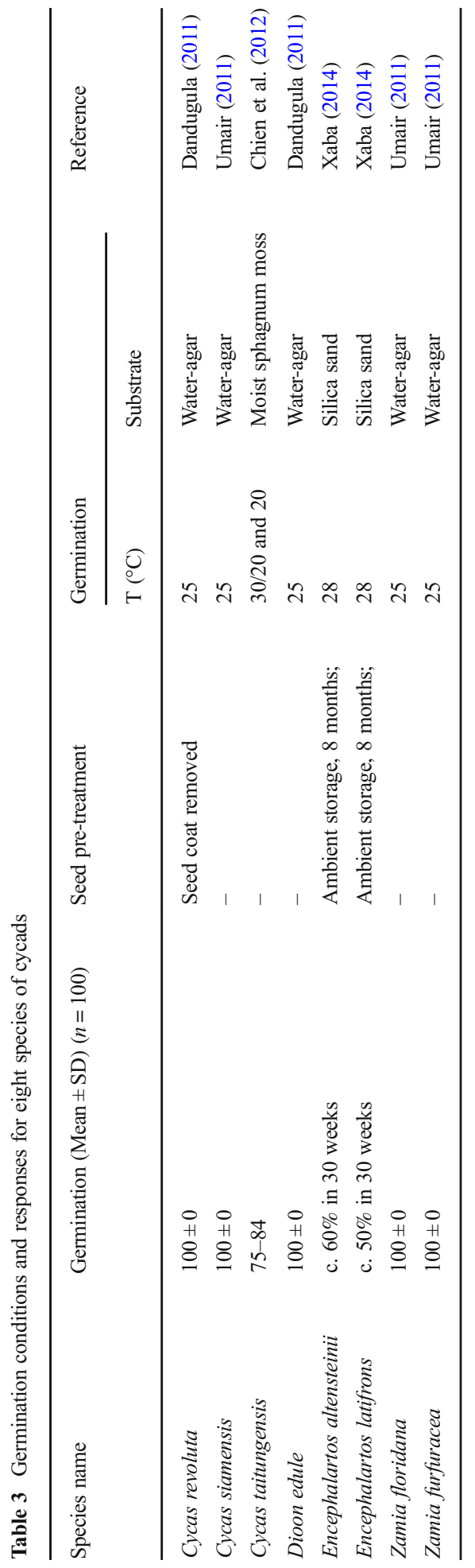


(Dehgan, 1996). Consequently, sulphuric acid digestion has been tried - a $25 \%$ concentration for $2 \mathrm{~h}$ increased germination rate in C. revoluta (about $30 \%$ earlier; 230 days vs 310 days); however, overall germination was lower than fresh seed (Zarchini et al., 2011). This indicates that care must be exercised when using acid treatments that might weaken the seed coat, therefore, chemical contact with the embryo should be avoided to minimise viability loss. Other forms of scarification may improve germination, such as the mechanical treatment (sanding down) of the coronula at the apex of the seed kernel, which is effective on the hard seeds of Dioon merolae (Perez-Farrera et al., 1999) and Encephalartos poggei. (Jones, 2002). Scarification by wet heat (i.e., hot water), can reduce the total germination in Cycas revoluta seeds (Zarchini et al., 2011).

In angiosperm seeds, slower germination is often observed when the embryo is relatively small, and might indicate the presence of some type of dormancy. Dormancy is the inability of the seed to germinate in a specified period under any combination of normal physical environmental factors that are otherwise favourable for its germination, i.e., after the seed becomes non-dormant (see Baskin and Baskin, 2014; Finch-Savage and Leubner-Metzger, 2006). Cycads are well known to have a very slow embryo development (Gifford and Foster, 1988; Singh, 1978) and seeds of most cycad species are dispersed whilst the embryos are relatively small. Subsequent slow germination in some cycads may reflect the need to complete embryo development and could indicate the presence of morphological or morpho-physiological dormancy. For example, embryo length relative to the seed (E:S ratio) varies considerably, from 0.17 in Cycas taitungensis to about 0.7 in Zamia furfuracea and Zamia floridana (Table 2). It appears that once the embryo has reached more than $50 \%$ of the length of the seed germination can be relatively rapid, e.g., within c. 30 days (Lindstrom, A., pers. comm). Relative embryo size can be a potential indicator of habitat and environmental stress tolerance in Apiaceae; a positive correlation was found between relative embryo length with germination speed, and negative correlation with the amount of habitat shade (Vandelook et al., 2012). Moreover in the family Grossulariaceae, species in the genus Ribes that disperse seeds with larger relative embryo lengths germinate more easily (Mattana et al., 2014). Similarly, there seems to be a correlation between initial relative embryo length at ripening and the natural habitat where the species occurs, e.g., distinct tropical species, such as E. ituriensis, germinate immediately at ripening while most South African Encephalartos need at many months storage prior to sowing and germination. For example, seeds of C. revoluta (Frett, 1987) and E. latifrons and E. altensteinii (Xaba, 2014) benefit from storage at room temperature for 6-12 months, after which they germinate faster than fresh seeds.

One recognised problem during cycad seed germination testing is that sowing seeds with small embryos immediately after harvest results in water uptake and expansion of the gametophyte and the opening of the sclerotesta. The exposed gametophyte tissue then often succumbs to fungal infections before the embryo has grown large enough to germinate.

Whilst the optimum temperatures for germination have been characterised for a wide range of seed species (Durr et al. 2015), detailed data on cycad seed temperature sensitivity is not yet available. Moreover, many questions remain unanswered concerning the nature of any dormancy present. These topics should be the focus of future research. 


\section{Tissue Biology}

Cycad conservation could potentially benefit from the application of in vitro technology and micropropagation (tissue culture), cryopreservation of cells and tissues and other innovative technologies, including molecular biology. Micropropagation may also support sustainable horticultural practices and the production of disease-free genetic resources. A knowledge of seed biology, phenology and seed and pollen storage behaviour will be pivotal to the application of conservation biotechnology to cycads. Cases in point are the use of seed-derived explants to initiate tissue cultures and the respective storage of zygotic and somatic embryos in traditional seed banks and in vitro genebanks in which tissue cultures are maintained in medium and long-term (cryogenic) storage (Litz et al., 2004). In this regard there has been some progress in recent years on the in vitro growth of cycad tissues (Teixeira da Silva et al., 2014).

\section{Marker Technologies}

Harding and Benson (2012) have recently reviewed the use of biomarkers in tropical plant conservation. With respect to cycads, molecular-biotechnological approaches can be applied in seed biology research and to facilitate the development of storage practices. Population genetics and taxonomic studies have applied cycad biomolecular markers (chloroplast and nuclear DNA sequence variation; ITS, ISSR, RAPD, SSR markers and AMOVA analysis) to study population structures and phylogenetic relationships. Calonje et al. (2011) used molecular techniques to develop and inform genetics-based conservation management and action plans for Zamia lucayana, the only cycad species endemic to the Bahamian archipelago, the habitats of which are at risk from urban development. In their study, sixteen microsatellite DNA markers were used to determine the number of management units required and to assess genetic structures of known populations. More recently single-copy nuclear gene technology has been used to describe the phylogeny of cycads, contributing to an accurate infra-familial classification of Zamiaceae (Salas-Leiva et al., 2013). Rousseau (2012) took a molecular systematic approach to 63 Encephalartos species to barcode various DNA regions (matK, rbcLa, psbA-trnH, and nrITS), finding that genetic variation was extremely low as was resolution at species level. Undoubtedly, DNA barcoding programmes do have the potential to support related cycad conservation activities (Chaw et al., 2005; Sass et al., 2007; Little and Stevenson, 2007). But to support law enforcement in the illegal cycad trade, modern technologies will need to provide unequivocal identity confirmation. The use of micro-chipping technology to tag cycads has had success in apprehending poachers / collectors acting illegally. Also, forensic chemistry of cells and tissues, pioneered on tropical timber, has been used to compare isotope signatures of wild cycads with specimens translocated decades ago (Nordling, 2014). This approach was successfully applied to two species in Encephalartos (E. lebomboensis and E. arenarius) by determining various isotopes (carbon, strontium, nitrogen, oxygen, sulphur) in the tissues (Retief et al., 2014). The prospect of identifying cycads growing ex situ that have been illegally traded is being explored further. 
With respect to reproductive biology, 16S rRNA mitochondrial genes have been used to study the lineages of weevils involved in cycad pollination (Tang et al., 2011). Biochemical markers (total protein, isozymes) and molecular markers (RAPDs, ISSR) have been tested to establish early sex differentiation to facilitate cycad conservation and sustainable management. Transcriptomics is also used for characterisation of male and female plants in C. elongata (Wang et al., 2011). Genes related to phytohormones and volatiles seems to suggests a complex molecular basis for sexual differentiation in cycads and this information could be used as biomarkers for sexual identification. Genes related to DNA methylation were also found to be associated with sexual differentiation in Cycas elongata, indicating the potential use of epigenetic biomarkers for sexual identification (Wang et al., 2011). Collectively these different molecular approaches may be used to support seed biology research and germplasm storage practices.

\section{Tissue Culture}

The IUCN-SSC Cycad Action Plan (Donaldson, 2003) highlights the potential for using in vitro propagation and tissue culture to improve germination, increase growth rates of seedlings, and develop plants from tissue culture for species with low seed set, all of which contribute to having more plants in cultivation. However, there have been comparatively few successes propagating cycads through tissue culture compared to other plant taxa (Dhiman and Rautela, 2014), with reports on only 17 species, representing $<5 \%$ coverage of species (Table 4 ). Genera of interest have been Encephalartos (five species), Zamia (four species), Ceratozamia and Cycas (three species each) and Stangeria (one species). A range of source tissues have used, particularly for studies involving $C$. revoluta (Teixeira da Silva et al., 2014; and references therein).

Early studies resulted in the asexual production of embryos from explanted somatic and reproductive (zygotic embryos/seed) tissues of Ceratozamia and Zamia (Chavez et al. $1992 \mathrm{a}, \mathrm{b}, \mathrm{c}$ ). Moreover, a range of generally routine methods for the production of somatic embryos have been developed by Litz and colleagues (Chavez et al. 1992 a, b, c; Chavez et al., 1994; Litz et al., 1995 a, b) but these have not, generally, resulted in the growth of whole plants. Megagametophytes and zygotic embryos have been used in most studies and in some cases, organogenesis has been reported from cut zygotic embryos (Table 4).

The lack of proven methods for the long-term storage of cycad seeds has resulted in the suggestion that cryopreservation may be the way forward for the long-term storage of cycad material, i.e., in cryobanks (Litz et al., 2004; Wade et al., 2016). Certainly, improvements in cycad tissue culture will expand the options for cryopreserving somatic embryos and rescuing zygotic embryos postcryo. Nonetheless, a cycad embryo cryopreservation method is yet to emerge. The development of in vitro methods for pollen germination will be a valuable adjunct to pollen storage studies, particularly as the successful cryopreservation of C. elongata pollen has been reported, achieving 90\% seed set (Yang et al., 2009). This will help to elevate the problem of a-synchronised coning in male and female plants as the pollen can be stored and tested for viability before conducting an artificial pollination. 


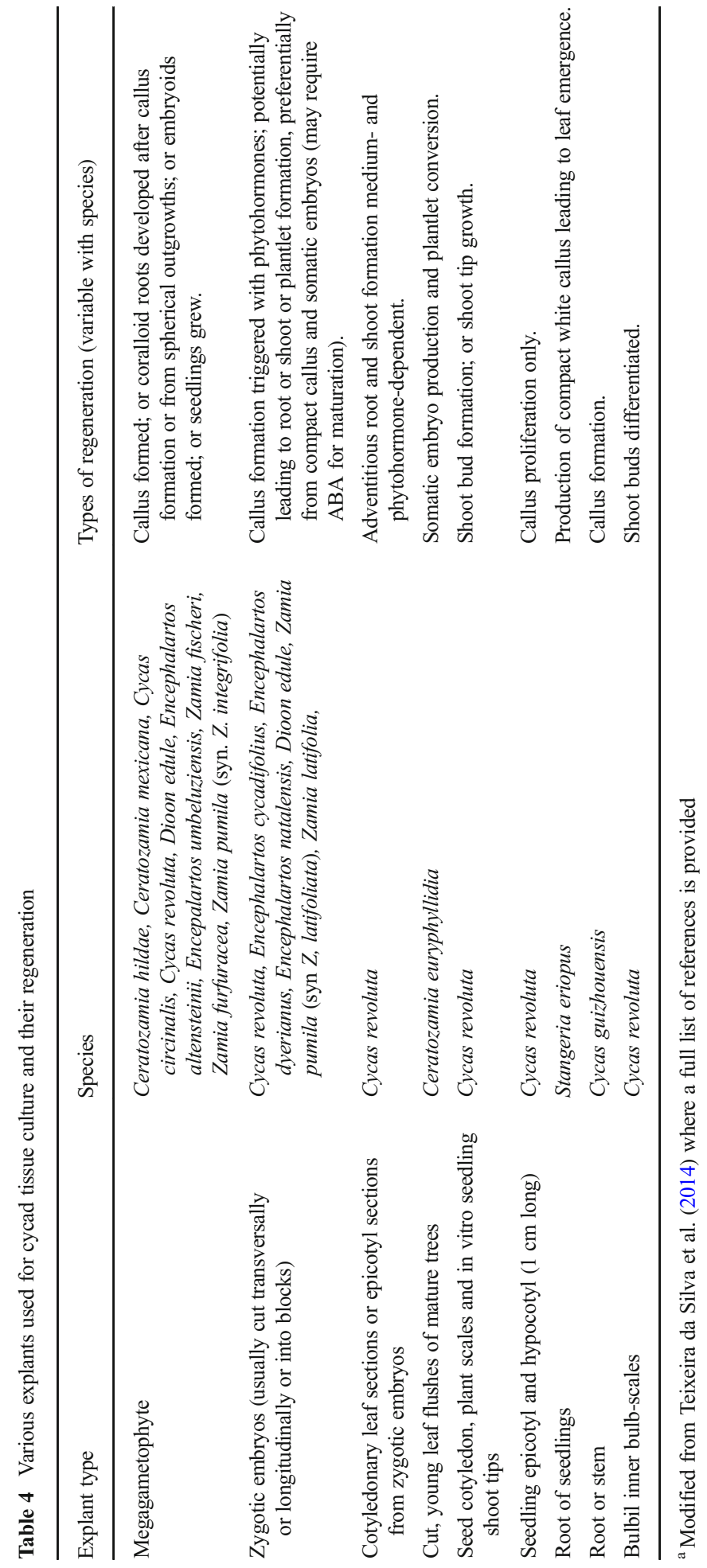




\section{Conclusions}

Best practices and efficiency measures have been developed for cycad horticulture in botanic gardens (Cuestas et al., 2011), resulting in the development of high quality collections - particularly in South Africa, Thailand and China - that help to safeguard against species loss in the natural environment. Such losses might accelerate due to many risk factors, including climate change related movement of diseases and pests (Ma et al., 2011). The 2010 provisions of the IUCN-CSG Action Plan (Donaldson, 2011) consider cycad risk mitigation with an emphasis on phytopathological issues. In this respect in vitro genebanks and cryobanks offer the advantages of enabling phytosanitary control and conserving disease-free cycad germplasm. The ready availability of germplasm for ex situ conservation and sustainable use will only be realised, however, by exploring the comparative seed and pollen biology of a much wider range of species than hitherto studied. Not only will such investigations improve understanding of species' physiological adaptations to the natural environment but also increase confidence in implementing assisted reproduction programmes for the most threatened cycads.

Acknowledgements Support from the Darwin Initiative (grant number 21-003) and Mohamed Bin Zayed Species Conservation Fund (Project number. 11253174) is gratefully acknowledged. The Royal Botanic Gardens, Kew receives grant-in-aid from DEFRA. The authors thank Richard Litz and Pat Moon (University of Florida) for information concerning cycad biotechnology.

Open Access This article is distributed under the terms of the Creative Commons Attribution 4.0 International License (http://creativecommons.org/licenses/by/4.0/), which permits unrestricted use, distribution, and reproduction in any medium, provided you give appropriate credit to the original author(s) and the source, provide a link to the Creative Commons license, and indicate if changes were made.

\section{References}

Ajeeshkumar, S., \& S.W. Decruse. 2013. Fertilizing ability of cryopreserved pollinia of Luisia macrantha, an endemic orchid of western Ghats. CryoLetters 34: 20-29.

Baskin, C., \& J. Baskin. 2014. Seeds: Ecology, Biogeography, and, Evolution of Dormancy and Germination, 2nd Edition. Academic press, 1600 pp.

Brummitt, N.A., S.P. Bachman, J. Griffiths-Lee, M. Lutz, J.F.Moat, A. Farjon, A., et al. 2015. Green Plants in the Red: A Baseline Global Assessment for the IUCN Sampled Red List Index for Plants. PLoS ONE 10(8): e0135152. https://doi.org/10.1371/journal.pone.0135152.

Calonje, M., A.W. Meerow, L. Knowles, D. Knowles, P. Griffith, \& J. Francisco-Ortega. 2011. Genetics-based conservation action plan for Zamia lucayana, the only cycad species endemic to the Bahamian archipelago (Caribbean Island biodiversity hotspot). Journal of Fairylake Botanical Garden 10: 43.

Calonje, M., D.W. Stevenson, \& L. Stanberg, L. 2017. The world list of cycads, online edition , 2013-2017. http://www.cycadlist.org.

Chamberlain, C.J. 1926. Hybrids in cycads. International Journal of Plant Sciences 81: 401-408.

Chamberlain, C. J. 1935. Gymnosperms: Structure and Evolution. University of Chicago Press, Chicago (reprinted 1965).

Chavez, V. M., R.E. Litz, P.A. Moon, \& K. Norstog. 1992a. Somatic embryogenesis from leaf callus of mature plants of the gymnosperm Ceratozamia mexicana var. robusta (Miq.) dyer (Cycadales). In vitro Cell Developmental Biology 28: 59-63. 
Chavez, V. M., R.E. Litz, P.A. Moon, \& K. Norstog. 1992b. In vitro morphogenesis of Ceratozamia hildae and C. mexicana from megagametophytes and zygotic embryos. Plant, cell, Tissue and Organ Culture 30: 93-98.

Chavez, V. M., R.E. Litz, P.A. Moon, \& K. Norstog. 1992c. Somatic embryogenesis and organogenesis in Zamia fischeri, Z. furfuraceae and Z. pumila. Plant cell, Tissue and Organ Culture 30: 99-105.

Chavez, V. M., R.E. Litz, A. Vovides, \& K. Norstog. 1994. Somatic embryogenesis from leaves of a mature plant of Ceratozamia euryphyllidia (Cycadales, Gymnospermae), an endangered species. VIIIth international congress of plant tissue and cell culture, 12-17 June, 1994, Firenze, abstract S11-22.

Chaw, S. M., T.W. Walters, C.C. Chang, S.H. Hu, \& S.H. Chen. 2005. A phylogeny of cycads (Cycadales) inferred from chloroplast matK gene, trnK intron, and nuclear rDNA ITS region. Molecular Phylogenetics Evolution 37: 214-234.

Chien C. T., S.Y. Cheng, S.H. Chang, \& J.D. Chung. 2012. Seed germination and storage of Cycas taitungensis (Cycadaceae). Taiwan Journal of Forest Science 27: 1-11.

Condamine, F.L., N.S. Nagalingum, C.R. Mashall, \& H. Morlon. 2015. Origin and diversification of living cycads: A cautionary tale on the impact of the branching process prior in Bayesian molecular dating. BMC Evolutionary Biology 15: 65. https://doi.org/10.1186/s12862-015-0347-8.

Cuestas, S., L. Anderson, M. Valcourt, C. Husby, M. Calonje, \& M.P. Griffith. 2011. Cycad horticulture at MBC: Best practices, new developments and new efficiencies. J Fairylake Botanical Garden 10: 59.

Daly, B., J.S. Donaldson, Y. Friedmann, Q. Hahndiek, N. King, D. Newton, \& A. Southwood. (Eds). 2006. Albany cycad (Encephalartos latifrons) population and habitat viability assessment workshop report. Conservation breeding specialist group (SSC / IUCN) / CBSG southern Africa. Endangered Wildlife Trust, Johannesburg.

Dadugula, S.R. 2011. Assessment of desiccation and freezing sensitivity towards development of cryopreservation protocols for three cycad species: Cycas revoluta, Dioon edule and Zamia furfuracea. MSc. Thesis, University and Bedfordshire and Royal Botanic Gardens Kew, UK.

Daws, M.I., N. Garwood, \& H.W. Pritchard. 2006. Predicting desiccation sensitivity in seeds of woody species: A probabalistic model based on two seed traits and 104 species. Annals of Botany 97: 667-674.

Dehgan, B. 1996. Permian permanence. American Nurseryman 183: 66.

Dehgan, B., \& N.B. Dehgan. 1988. Comparative pollen morphology and taxonomic affinities in Cycadales. American Journal of Botany 75: 1501-1516.

Dehgan, B., \& B. Schutzman. 1989. Embryo development and germination of Cycas seeds. Journal of the American Society for Horticultural Science, 114: 125-129.

Dehgan, B., \& C.K.K.H. Yuen. 1983. Seed morphology in relation to dispersal, evolution, and propagation of Cycas L. Botanical Gazette 144: 412-418.

Dhiman, M., \& I. Rautela. 2014. Biotechnological approaches towards micropropagation and conservation of cycads and Ephedrales. In: M. R. Ahuja, K.G. Ramawat (eds), Biotechnology and biodiversity, volume 4 of sustainable development and biodiversity, pp 247-270.

Dickie, J.B., \& H.W. Pritchard. 2002. Systematic and evolutionary aspects of desiccation tolerance in seeds. Pp 239-259. In: MM Black \& H.W. Pritchard (eds), Desiccation and survival in plants: Drying without dying. CABI Publishing, UK.

Donaldson, J. S. 1997. Is there floral parasite mutualism pollination in cycads? Pollination biology of Encephalartos villosus (Zamiaceae). American Journal of Botany 84: 1398-1406.

Donaldson, J. S. 2003. Cycads: Status Survey and Conservation Action Plan. IUCN/SSC Cycad Specialist Group, IUCN, Gland, Switzerland and Cambridge, UK.

Donaldson, J. S. 2011. An overview of cycad conservation based on the 2010 global cycad assessment and its implications for the IUCN/SSC cycad action plan. Journal of Fairylake botanical Garden 10: 47.

Donaldson, J.S., \& J.D. Bösenberg. 1995. Life history and host range of the leopard magpie moth, Zerenopsis leopardina Felder (Lepidoptera: Geometridae). African Entomology 3: 103-110.

Dürr, C., J.B. Dickie, X-Y. Yang, \& H.W. Pritchard, H.W. 2015. Ranges of critical temperature and water potential values for the germination of species worldwide: Contribution to a seed trait database. Agricultural and Forest Meteorology 200: 222-232.

Fernando, D.D., C.R. Quin, E.D. Brenner, \& J.N. Owens. 2010. Male gametophyte development and evolution in extant gymnosperms. International journal of plant developmental biology 47-63. Global Science Books.

Fernando, D.D., M.D. Lazzaro, \& J.N. Owens. 2005. Growth and development of conifer pollen tubes. Sexual Plant Reproduction 18: 149-162.

Fragniere, Y., S. Betrisey, L. Cardinaux, M. Stoffel, \& G. Kozlowski. 2015. Fighting their last stand? A global analysis of the distribution and conservation status of gymnosperms. Journal of Biogeography 42: 809820. 
Finch-Savage, W.E., \& G. Leubner-Metzger. 2006. Seed dormancy and the control of germination. New Phytologist 171: 501-523.

Forsyth, C., \& J. van Staden. 1983. Germination of cycad seeds. South African Journal of Science 79: 8-9.

Frett, J.J. 1987. Seed germination of Cycas revoluta. Journal of Environmental Horticulture 5: 105-106.

Gifford, E. M., \& AS Foster. 1988. Morphology and evolution of vascular plants. $3^{\text {rd }}$ Edition. W. H. Freeman and Co., New York.

Griffith, M. P., M. Calonje, A.W. Meerow, F. Tut, A.T. Kramer, \& A. Hird. 2015. Can a botanic garden cycad collection capture the genetic diversity in a wild population? International Journal of Plant Sciences 176: 1-10. https://doi.org/10.1086/678466

Grobbelaar, N. 1996. Growth of cycad female cones and their omnule after the cones have become receptive to pollination. Pp 276-279. In: C.J. Chen (ed). Proceedings of the fourth international conference on cycad biology International academic Publishers, Beijing.

Grobbelaar, N. 2002. Cycads: With special reference to the southern African species. First edition. Privately Published, Pretoria.

Harding, K., \& E.E. Benson. 2012. Biomarkers from molecules to ecosystems and biobanks to genebanks. Pp 121-133. In: N. M Noor, H. F. Chin, B. M. Reed (eds). Conservation of tropical plant species, Springer, New York.

Huang, Z. Y. 2011. Research on reproduction in Cycas revoluta. Journal of Fairylake Botanical Garden 10: 73.

IUCN 2016. The IUCN red list of threatened species. Version 2016-3. http://www.iucnredlist.org.

Jacot-Guillarmod, A. 1958. Temperature variation in male cones of Encephalartos. Nature 182: 474.

Jones, D. L. 2002. Cycads of the world. 2nd ed. Washington, D.C: Smithsonian Institution Press.

Kay, J.A., A. Strader, V. Murphy, L. Nghiem-Phu, M. Calonje, \& M.P. Griffith. 2011. Palma Corcho: A case study in botanic garden conservation horticulture and economics. Horticulture Technology 21: 478-481.

Langkamp, P., \& M. Plaisted. 1987. Appendix 1. Native plant seed usage by the mining industry - a survey. Pp 135-191. In: P. Langkamp (ed), Germination of Australian native plant seed. Inkata Press, Melbourne, Sydney.

Liddle, D. T. 2009. Management program for Cycads in the Northern Territory of Australia 2009-2014. pp 37. Northern Territory Department of Natural Resources, Environment, the Arts and Sport, Darwin, Australia.

Little, D. P. \& D. W. Stevenson. 2007. A comparison of algorithms for the identification of specimens using DNA barcodes: Examples from gymnosperms. Cladistics 22: 1-21.

Litz, R. E., P.A. Moon, E.E. Benson, J. Stewart, \& V.M. Chavez. 2004. A biotechnology strategy for medium and long-term conservation of cycads. The Botanical Review 70: 39-46.

Litz, R.E., P.A. Moon, \& V.M. Chavez. 2005. Somatic embryogenesis and regeneration of endangered cycad species. Proceedings of the 11th international society on biotechnology of tropical and sub tropical species. Acta Horticulture, no. 692: 75-79.

Litz, R.E., V.M. Chavez, \& P.A. Moon. 1995a. Somatic embryogenesis in the Cycadales. Pp 1-15. In: S. Jain, P. Gupta, \& R. Newton (eds). Somatic embryogenesis in Woody plants, vol. 3, Kluwer Academic Publishers, Dordrecht.

Litz, R.E., V.M. Chavez, \& P.A. Moon. 1995b. Somatic embryogenesis from leaf callus derived from mature trees of the cycad Ceratozamia hildae Gynmospermae. Plant Cell, Tissue and Organ Culture 40: 25-31.

Ma, W. J., N. Li, X.R. Wang, S. Sun, L.L. Ren, J.A. Zhang, Q.H. Zhong. 2011. Risk analysis on cycad diseases in the global world. Journal of Fairylake Botanical Garden 10: 67.

Ma, Y., G. Chen, R.E. Grumbine, Z. Dao, W. Sun, \& H. Guo. 2013. Conserving plant species with extremely small populations (PSESP) in China. Biodiversity and Conservation 22: 803-809.

Marshall, J., N. Grobbelaar, J. Coetzee, \& R. Osborne. 1989. Pollen morphology of the Cycadales with special reference to the Encephalartos species. Pollen et Spores 31: 229-249.

Mattana, E., W.H. Stuppy, R. Fraser, J. Waller, \& H.W. Pritchard. 2014. Dependency of seed dormancy types on embryo traits and environmental conditions in Ribes species. Plant Biology 16: 740-747.

Marks, T.R., P.T. Seaton, \& H.W. Pritchard. 2014. Desiccation tolerance, longevity and seed-siring ability of entomophilous pollen from UK native orchid species. Annals of Botany 114: 561-569.

Marler, P. N., \& T.E. Marler. 2015. An assessment of red list data for the Cycadales. Tropical Conservation Science 8: 1114-1125. Available online: www.tropicalconservationscience.org.

Mostert, C. 2000. Aspekte van die Keimingsgedrag en Fynstruktuur van Encephalartos stuimeel. MSc Thesis. University of Pretoria, South Africa.

Nagalingum, N.S., C.R. Marshall, T.B. Quental, H.S. Rai, D.P. Little, \& S. Mathews. 2011. Recent synchronous radiation of a living fossil. Science 334: 796-799.

Negron-Ortiz V., D.L. Gorchov, \& G.J. Breckon. 1996. Population structure in Zamia (Zamiaceae) in northern Puerto Rico. II. Seed germination and stage-structured population projection. International Journal of Plant Sciences 157:, 605-614. 
Nordling, L. 2014. Forensic chemistry could stop plant thieves. Nature 514: 17.

Norstog, K. 1977. The spermatozoid of Zamia chigua seem. Botanical Gazette 38: 409-412.

Norstog, K., E.M. Gifford, \& D.W. Stevenson. 2004. Comparative development of spermatozoids of cycads and Ginkgo bioloba. Botanical Review 70: 5-15.

Norstog, K.J., \& T.J. Nicholls. (eds.). 1997. The biology of the cycads. 363 pp. Cornell University Press, Ithaca, United States of America.

Osborne, R., M.A. Calonje, K.D. Hill, L. Stanberg, \& D.W. Stevenson. 2012. The world list of cycads. Memoirs New York Botanical Garden 106: 480-510.

Osborne, R., P.J. Robbertse, \& M.I. Claassen. 1991. The longevity of cycad pollen - Results of some preliminary experiments. Encephalartos (J. Cycad Soc. S. Afr.) 28: 10-13.

Osborne, R., P.J. Robbertse, \& M.I. Claassen. 1992. The longevity of cycad pollen in storage. South African Journal of Botany 58: 250-254.

Ouyang, H., S. Zhang, N. Li, \& H. Wu. 2004. Microsporogenesis of Cycas elongate and it systematic implication. Acta Phytotaxonomica Sinica 42: 500-512.

Pacini, E., G.G. Franchi, \& M. Ripaccioli. 1999. Ripe pollen structure and histochemistry of some gymnosperms. Plant Systematics and Evolution 217: 81-99.

Perez-Farrera, M. A., A. P. Vovides, \& J.G. Alavarez-Moctezuma. 1999. A study on seed germination. The New Plantsman 6: 214-218.

Poisson, M.J. 1878. Du dégagement de chaleur qui accompagne l'épanouissement des inflorescences males de Dioon edule. Bulletin de la Societe Botanique de France 25: 253-254.

Prior, N.A. 2014. Proteins in Gymnosperm Pollination Drops. PhD Thesis, University of Victoria, Canada (http://hdl.handle.net/1828/5776)

Pritchard, H. W., A. Lindstrom, N. Li, \& J. Nadarajan. 2011. Integrated conservation of ancient plants. Abstracts of the $9^{\text {th }}$ Intl Conf on cycad biology, Journal of Fairylake Botanical Garden 10: 11.

Pritchard, H.W., J. Moat, J.B.S. Ferraz, T.R. Marks, J.L.C. Camargo, J. Nadarajan, \& I.D.K. Ferraz. 2014. Innovative approaches to the preservation of tree species. Forest Ecology \& Management 33: 88-98.

Raju, A.J.S., \& N.G. Rao. 2011. Taxonomic aspects and coning ecology of Cycas circinalis L. (Cycadales: Cycadaceae), a threatened species of India. Journal of Threatened Taxa 3: 1425-1431.

Retief, K., A.G. West, \& M.F. Pfab. 2014. Can stable isotopes and radiocarbon dating provide a forensic solution for curbing illegal harvesting of threatened cycads? Journal of Forensic Sciences 59: 1541-1551.

Rousseau, P. 2012. A molecular systematic study of the African endemic cycads. MSc thesis, Univ. Johannesburg. Uri: http://hdl.handle.net/10210/5990.

Salas-Leiva, D.E., A.W. Meerow, M. Calonje, M.P. Griffith, J. Francisco-Ortega, K. Nakamura, D.W. Stevenson, C.E. Lewis, \& S. Namoff. 2013. Phylogeny of the cycads based on multiple single-copy nuclear genes: Congruence of concatenated parsimony, likelihood and species tree inference methods. Annals of Botany 112: 1263-1278.

Sass, C., D.P. Little, D.W. Stevenson, \& C.D. Specht. 2007. DNA Barcoding in the Cycadales: testing the potential of proposed barcoding markers for species identification of Cycads. PLoS ONE 2(11): e1154.

Singh, H. 1978. Embryology of gymnosperms. Handbuch der Pfanzenanatomie Bd 10, T 2. Gebruder Borntraeger, Berlin.

Stanley, R. G., \& H.F. Linskens. 1974. Pollen biology, biochemistry, management. Springer-Verlag, Berlin, Heidelberg, New York.

Stevenson, D., K. Norstog, \& P. Fawcett. 1998. Pollination biology of cycads. Pp. 277-294. In: Reproductive biology: In systematics, conservation, and economic botany. S. Owens \& P. Rudall (eds), Royal Botanic Gardens, Kew, UK.

Suinyuy, T.N., J.S. Donaldson, \& S.D. Johnson. 2010. Scent chemistry and patterns of thermogenesis in male and female cones of the African cycad Encephalartos natalensis (Zamiaceae). South African Journal of Botany 7: 717-725.

Tang, W. 1986. Pollinating cycads. Encephalartos 8: 16-19.

Tang, W. 1987. Heat production in cycad cones. Botanical Gazette 148: 165-174.

Tang, W., G. Xu, A. Lindstrom, T. Marler, R. Singh, J.K. Singh, P. Radha, \& S. Rich. 2011. Weevils in the cones of Asian Cycas: Their phylogeny based on analysis of 16S rRNA mitochondrial gene. Journal of Fairylake Botanical Garden 10: 28.

Teixeira da Silva, J.A., W.R. Woodenberg, \& SA. Zeng. 2014. Cycads in vitro. Plant Tissue Culture \& Biotechnology 24: 287-301.

Terry, I., C.J. Moore, G.H. Walter, P.I. Voster, R.B. Roemer, J.S. Donaldson, \& P.J. Machin. 2004. Association of cone thermogenesis and volatiles with pollinator specificity in Macrozamia cycads. Plant Systematics and Evolution 243: 233-247. 
Thien, L.B., H. Azuma, \& S. Kawano. 2010. New perspectives on the pollination biology of basal angiosperms. International Journal of Plant Sciences 161, no. S6 (November 2000): S225-S235.

Umair, S. 2011. Cycad Seed Biology and Embryo Cryopreservation: Especially Cycas siamensis, Dioon edule and Zamia floridana. MSc Thesis, University of Bedfordshire and Royal Botanic Gardens Kew, UK.

Vandelook, F., S.B. Janssens, R.J. Probert. 2012. Relative embryo length as an adaptation to habitat and life cycle in Apiaceae. New Phytologist 195: 479-487.

Vovides, A.P. 1990. Spatial distribution, survival, and fecundity of Dioon edule (Zamiaceae) in a tropical deciduous forest in Veracruz, Mexico with notes on its habitat. American Journal of Botany 77: 15321543.

Wade, E. M., J. Nadarajan, X-Y Yang, D. Ballesteros, W_B. Sun, \& H.W. Pritchard. 2016. Plant species with extremely small populations (PSESP) in China: A seed and spore biology perspective. Plant Diversity 38 : 209-220.

Wang, Y., Q. Yang, Y. Li, H. Wu, \& S.Z. Zhang. 2011. Transcriptome characterization for male and female plants of Cycas elongata (Leandri) D.Y. Wang. Journal of Fairylake Botanical Garden 10: 69.

Williams, J.H. 2008. Novelties of flowering plant pollen tube underline diversification of a key life history stage. Proceedings of the National Academy of Sciences 105: 11259-11263.

Witte, W.T. 1977. Storage and germination of Zamia seed. Proceedings of the Florida state horticultural Society 90: 89-91.

Xaba, P M A. 2014. Pollination and Germination as Limiting Factors in the Propagation of Threatened Cycads, Encephalartos (Zamiaceae). MSc Thesis, University of Western Cape, South Africa. 154 pp.

Yang, Q-G., N. Li, Z-G Li, Z-G. Lin, P.Y. Lin, \& B. Luo. 2009. Studies on pollen germination of Cycas species. Gihaia 29: 673-677.

Yatomi, R., S. Nakamura, \& N. Nakamura. 2002. Immunochemical and cytochemical detection of wall components of germinated pollen of gymnosperms. Grana 41: 21-28.

Zarchini, M., D. Hashemabadi, B. Kaviani, P.R. Fallahabadi, \& N. Negahdar. 2011. Improved germination conditions in Cycas revoluta L. by using sulfuric acid and hot water. Plant Omics Journal 4: 350-353. 